\title{
Role of serum procalcitonin in monitoring the response to treatment of pediatric meningitis
}

\author{
Ahmad M. ${ }^{1}$, lqbal J. ${ }^{2}$, Ahmad Wani F. ${ }^{3}$, Wajid Ali S. ${ }^{4}$ \\ DOI: https://doi.org/10.17511/ijpr.2020.i07.06 \\ 1 Mudasir Ahmad, DNB Scholar, Department of Pediatric Cardiology, Fortis Escorts Heart Institute, New Delhi, , India. \\ 2 Javeed Iqbal, Associate Professor, Department of Neonatology and Pediatrics, Sher-i-Kashmir Institute of Medical Sciences (SKIMS), \\ Srinagar, Jammu and Kashmir, India. \\ ${ }^{3}$ Feroz Ahmad Wani, Lecturer, Department of Community Medicine, Govt. Medical College, Srinagar, Jammu and Kashmir, India. \\ 4 Syed Wajid Ali, Ex-Professor, Department of Neonatology and Pediatrics, Sher-i-Kashmir Institute of Medical Sciences (SKIMS), Srinagar, \\ Jammu and Kashmir, India. \\ Introduction: A good early diagnostic and prognostic marker for bacterial meningitis will decrease \\ the morbidity and mortality due to this infection. Serum procalcitonin has been evaluated for \\ usefulness in diagnosis and as a prognostic marker in bacterial meningitis. Methods: Children from \\ 5 months to 15 years of age who were cases of bacterial meningitis as per WHO Criteria and were \\ admitted to the Pediatric Department in SKIMS Srinagar, Jammu, and Kashmir were taken for the \\ study. A total of 45 bacterial meningitis cases participated in this prospective study. Serum PCT was \\ measured by a fluorescence immunoassay using QDX Insta check with a detection limit of 0.25-100 \\ $\mathrm{ng} / \mathrm{ml}$. Data were analyzed using standard statistical tests using SPSS 20. Results: The mean \\ serum PCT on admission in $\mathrm{ng} / \mathrm{ml}$ in the present study for bacterial meningitis was \\ $14.9293 \pm 4.49122$ and after 72 hours mean serum PCT was 12.4386 4 4.40964). A significant drop \\ (mean difference $=2.49086 ; p=0.000$ ) in serum procalcitonin was seen after 72 hours following \\ antibacterial treatment. Conclusion: It was concluded that serum PCT can be used as a good \\ prognostic marker to see the response to treatment in bacterial meningitis.
}

Keywords: Procalcitonin, Meningitis, Pediatrics

Corresponding Author

Feroz Ahmad Wani, Lecturer, Department of Community Medicine, Govt. Medical College, Srinagar, Jammu and Kashmir, India.

Email: drferoz47@gmail.com
How to Cite this Article

To Browse

Ahmad M, Iqbal J, Wani FA, Ali SW. Role of serum procalcitonin in monitoring the response to treatment of pediatric meningitis. Pediatric Rev Int J Pediatr Res. 2020;7(7):351-355.

Available From

https://pediatrics.medresearch.in/index.php/ijpr/arti cle/view/626

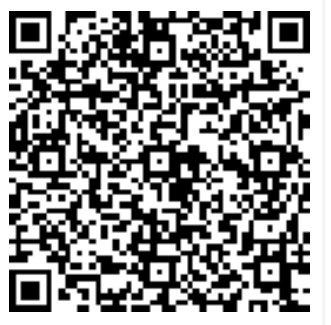

Manuscript Received 2020-09-12

Conflict of Interest No

Review Round 1
2020-09-22
Funding
Nil

$\begin{gathered}\text { Review Round } 2 \\ 2020-09-30\end{gathered}$
Ethical Approval
Yes

Review Round 2 Yes
Review Round 3

Accepted 2020-10-05

Plagiarism X-checker $6 \%$

(c) 2020 by Mudasir Ahmad, Javeed Iqbal, Feroz Ahmad Wani, Syed Wajid Ali and Published by Siddharth Health Research and Social Welfare Society. This is an Open Access article licensed under a Creative Commons Attribution 4.0 International License https://creativecommons.org/licenses/by/4.0/ unported [CC BY 4.0]. 


\section{Introduction}

Meningitis is a severe acute infectious disease caused by several microorganisms, including viruses, bacteria, parasites, and fungi. Fatality rates associated with this disease can be as low as $2 \%$ in infants and children, and as high as $20-30 \%$ in neonates and adults [1]. Transient or permanent deafness, or other neurological sequelae, arise in up to a third of survivors [2].

The frequency of neonatal meningitis varies greatly between different institutions and geographical areas, with rates of about two to ten cases per 10 000 live births [3]. More than two-thirds of all cases of neonatal meningitis in developed countries are caused by group B streptococci and gram-negative enteric bacilli. In developing countries, gramnegative enteric bacilli are the predominant organisms causing bacterial meningitis in newborns; however, group B streptococci and $L$. monocytogenes have been isolated increasingly [4]. Infections are mostly acquired by vertical transmission, but the nosocomial transmission is also important, especially in preterm infants with low birth weight who require long-term intensive care. Although nearly all newborn infants are colonized by many of the organisms with which they have contact, sepsis arises in less than $1 \%$ of these infants. About $25 \%$ of infants with septicemia develop meningitis [5].

In the neonatal period, pathogens are acquired mainly, although not exclusively, during birth by contact and aspiration of intestinal and genital tract secretions from the mother. In infants and children, meningitis usually develops after encapsulated bacteria that have colonized the nasopharynx are disseminated in the blood. Viral infections of the upper respiratory tract commonly precede invasion of the bloodstream. Subsequently, organisms penetrate vulnerable sites of the blood-brain barrier (e.g., choroid plexus and cerebral capillaries) and reach the subarachnoid space [6]. Meningitis can also develop by direct extension of infection from a paranasal sinus, middle ear, congenital dural defects, neurosurgical procedures, or head trauma with a skull fracture.

The intense inflammation within the subarachnoid space noted in lumbar CSF, and the resulting neurological damage, are not the direct result of the pathogenic bacteria but rather of activation [7] of the host's inflammatory pathways by the microorganisms or their products.
The clinical picture of acute bacterial meningitis mainly depends on the patient's age. The classic manifestations noted in older children and adults are rarely present in infants. As the CSF inflammatory response intensifies in bacterial meningitis, the most consistent physical finding, in children and adults, is the presence of nuchal rigidity associated with Brudzinski's and Kernig's signs appear. These signs and symptoms are common to all types of meningitis [8].

A good biomarker for meningitis should provide early diagnosis, be a good prognostic marker, and be helpful for therapeutic antimicrobial decisions. Because the consequences of delayed diagnosis of bacterial meningitis can be severe, any proposed diagnostic tool must achieve near $100 \%$ sensitivity [9].

Among new markers, serum procalcitonin (PCT) level seems to be one of the most sensitive and specific predictors for discriminating between bacterial and non-bacterial infections [10] because PCT expression is only slightly induced, if at all, by viral infections, autoimmune diseases, neoplastic diseases and trauma of surgical intervention [11].

Only a few published studies have focused on the value of serum PCT for therapeutic decisions in meningitis and present conflicting results. Hence a current study was designed to see the role of serum procalcitonin as a therapeutic marker in bacterial meningitis in the pediatric age group i.e. to see the role of serum procalcitonin in determining the response to treatment.

\section{Material and methods}

This study was conducted among suspected cases of bacterial meningitis who were admitted to the Department of Neonatology and Pediatrics in SKIMS, Srinagar.

Duration and type of study: The prospective type of study was conducted over 1 year.

Sampling methods: All the suspected cases of pediatric meningitis were enrolled for the study.

Sample size calculation: A total of 45bacterial meningitis cases defined as per the WHO definition of meningitis participated in the study.

Inclusion criteria: Children from age 5 months to 15 years of age who were suspected cases of bacterial meningitis and were admitted to the hospital. 
Exclusion criteria: Children below 5 months of age and cases who had received antibiotics in the past seven days were excluded from the study.

Data collection procedure: All relevant demographic information as well as clinical symptoms and signs were recorded on admission on a self-structured proforma. Serum was separated from blood samples collected on admission from all patients and stored at $-200 \mathrm{C}$ and used subsequently for assaying PCT. After $72 \mathrm{~h}$ of treatment, serum PCT levels were re-estimated. The prognosis of cases was followed over 7 days. Serum PCT was measured by a fluorescence immunoassay using QDX Instacheck. It is a quantitative test requiring $150 \mu \mathrm{l}$ of serum. The signal intensity of fluorescence on the detector antibody reflects the amount of antigen captured and is processed by the QDX Instacheck Reader. The detection limit is 0.25$100 \mathrm{ng} / \mathrm{ml}$. The normal serum procalcitonin with this is $<0.5 \mathrm{ng} / \mathrm{ml}$.

Ethical consideration and permission: Informed consent was taken from the parents for the participation of their children in the study. Permission for the study was sought from the institutional ethical committee (IEC SKIMS).

Data Analysis: Data was entered and analyzed by using standard statistical tests using SPSS 20. Variables were compared employing tests chisquare and student's t-tests whichever feasible. Values were expressed as mean \pm SD and $p$-value < 0.05 was considered significant.

\section{Results}

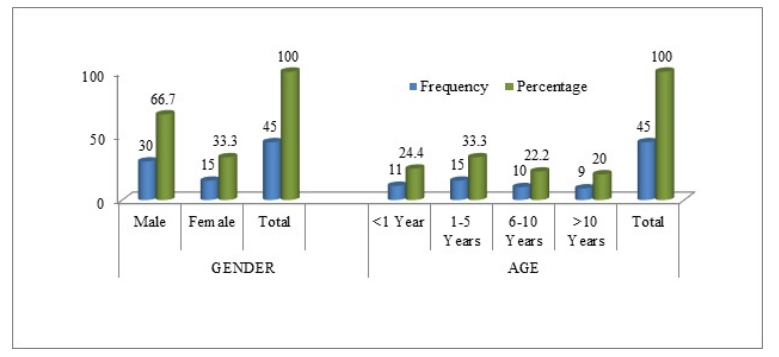

\section{Fig-1: Demographic profile of the study population.}

Figure 1 shows the demographic features of the study population. Of the total 45 participants, 30 $(66.7 \%)$ were males and $15(33.3 \%)$ were females. $11(24.4 \%)$ had age $<1$ year, $15(33.3 \%)$ were in the age group $1-5$ years, $10(22.2 \%)$ in the age group of $6-10$ years, and $9(20 \%)>10$ years.
Table-1: Physical characteristics of the study population.

\begin{tabular}{|l|l|l|l|l|}
\hline & \multicolumn{1}{|c|}{ Age } & \multicolumn{1}{c|}{ Height } & \multicolumn{1}{c|}{ Weight } & \multicolumn{1}{c|}{ BMI } \\
\hline N & 45 & 45 & 45 & 21 \\
\hline Mean & 4.978 & 98.589 & 17.322 & 16.348 \\
\hline Std. Deviation & 4.5992 & 28.1395 & 10.7482 & 2.2728 \\
\hline
\end{tabular}

Table 1 shows the physical characteristics of the study population. The mean age of the participants was 4.978 Years $(S D=4.5992)$, mean height was $98.589 \mathrm{~cm}(\mathrm{SD}=28.1395)$, mean weight was 17.322 $\mathrm{kg}(\mathrm{SD}=10.7482)$, and mean BMI of cases $(n=21)$ was $16.348 \mathrm{~kg} / \mathrm{m} 2(\mathrm{SD}=2.2728)$.

Table-2: Paired sample (paired t-test) statistics for serum procalcitonin.

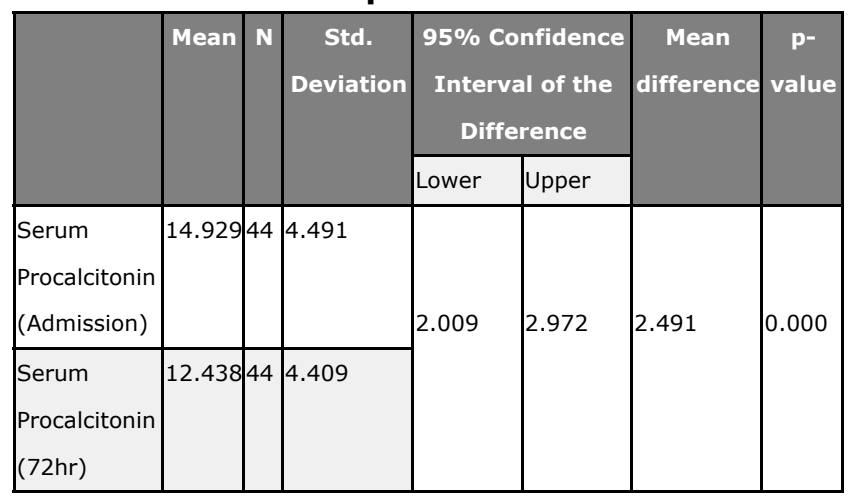

Table 2 shows the response of serum procalcitonin to treatment after 72 hours in bacterial meningitis. There is a significant drop (mean difference = $2.49086 ; p=0.000)$ in serum procalcitonin after 72 hours (mean $=12.4386$ ) of treatment compared to serum procalcitonin on admission (mean $=14.9293$ ).

\section{Discussion}

This observational study was conducted in the Department of Neonatology and Paediatric of SKIMS Srinagar to study the role of serum PCT in checking the response to treatment of bacterial meningitis. The study was done on patients who were admitted to the pediatric department and were diagnosed as cases of bacterial meningitis as per WHO criteria. The study included a total of 45 cases of bacterial meningitis. Meningitis is one of the most common causes of admissions in hospitals in the pediatric age group. It is commonly diagnosed by signs, symptoms, and laboratory investigations. In the last few years, serum PCT level has been reported to be useful in the establishment of severe bacterial infections and in the follow up of treatment. The aim and objective of the study were to investigate whether there is any role of serum PCT in checking the response to treatment of bacterial meningitis. 
A total of 30(66.7\%) males and $15(33.3 \%)$ females participated in the study. Serum PCT was estimated on admission and also after 72 hours of starting treatment to study whether there is any significant drop in serum PCT, the mean serum PCT level at admission, and 72 hours of treatment of this group $(n=45)$ were 14.9293; $S D=4.4912$ and 12.4386; $\mathrm{SD}=4.4096$ respectively.

The drop in serum PCT was highly significant $(p<0.001)$ and was consistent with the study conducted by Alavi SM, et al (2012) [12] with mean serum PCT at admission and 72 hours as $2.58 \pm 4.62$ and $1.52 \pm 3.03 \mathrm{ng} / \mathrm{ml}$, respectively and was also consistent with the study conducted by Ibrahim KA et al [13] in which follow up of the studied cases, showed a significant decrease in procalcitonin levels on day 3 and day 6 after antibiotic treatment.

Viallon A et al (2005) observed that median serum PCT levels on admission and at day 2 were 4.5 $(2.8-10.8) \mathrm{mg} / \mathrm{ml}$ and 2 (0.9-5.0) $\mathrm{mg} / \mathrm{ml}$, respectively $(P<0.0001)$ [14].

This result is again consistent with that obtained by many authors, [15-17] who found that serum procalcitonin decreased to a very low, and may to an unidentifiable level with treatment, making it a valuable parameter for evaluating the efficacy of antibiotic treatment and hence diminishing the need for lumbar puncture performed 48-72 hours after admission to assess treatment efficacy.

Gendrel D et al (1997) observed that all the patients followed for PCT levels had $<1 \mathrm{mg} / \mathrm{L}$ of PCT at recovery [18].

Further, it was observed by Schwarz S et al (2000) that persistently elevated or increasing PCT levels after 2 days of admission were associated with unfavorable clinical outcomes [19].

These findings are in agreement with Monneret $\mathrm{G}$ et al (1997) study where they found that high levels of PCT correlated with bacterial invasion and PCT returned to normal range $(<0.1$ micrograms) more quickly than C-reactive protein, suggesting that PCT may be an early marker of favorable outcome [20].

\section{Limitations}

The study was dependent on the number of pediatric meningitis cases admitted to the hospital. Only 45 participants during the one year full filled the inclusion criteria.

\section{Conclusion}

Therefore, it was concluded that serum procalcitonin besides being a diagnostic marker for meningitis is also a good follow-up tool to see the response to treatment.

\section{Author's Contributions}

Dr. Mudasir Ahmad and Dr. Javeed Iqbal were involved in the collection of data. Dr. Feroz Ahmad Wani was involved in the analysis of data and preparation of the manuscript. The study was conducted under the overall supervision of Dr. Syed Wajid Ali.

\section{Reference}

01. Sáez-Llorens X, McCracken GH Jr. Bacterial meningitis in neonates and children. Infect Dis Clin North Am. 1990;4(4)623-644.

[Crossref]

02. Neuman HB, Wald ER. Bacterial meningitis in childhood at the Children's Hospital of Pittsburgh- 1988-1998. Clin Pediatr (Phila). 2001;40(11)595-600.

doi: $10.1177 / 000992280104001102 \quad$ [Crossref]

03. Klein JO, Feigin RD, McCracken GH Jr. Report of the task force on diagnosis and management of meningitis. Pediatr. 1986;78(5 Pt 2)959-982.

[Crossref]

04. Moreno MT, Vargas S, Poveda R, Sáez-Llorens X. Neonatal sepsis and meningitis in a developing Latin American country. Pediatr Infect Dis $\mathrm{J}$. $1994 ; 13(6) 516-520$. doi: 10.1097/00006454-199406000-00010 [Crossref]

05. Sáez-Llorens X, McCracken GJ Jr. Antimicrobial and anti-inflammatory treatment of bacterial meningitis. Infect Dis Clin North Am. 1999;13(3)619-636, vii.

doi: $10.1016 / \mathrm{s} 0891-5520(05) 70097-0$ [Crossref]

06. Leib SL, Tauber MG. Pathogenesis of bacterial meningitis. Infect Dis Clin North Am. $1999 ; 13(3) 527-548$.

doi: $10.1007 / \mathrm{bf01641732}$ [Crossref] 
07. Sáez-Llorens X, Ramilo O, Mustafa MM, Mertsola J, McCracken GH Jr. Molecular pathophysiology of bacterial meningitis- current concepts and therapeutic implications. J Pediatr. $1990 ; 116(5) 671-84$.

doi: $10.1016 / \mathrm{s} 0022-3476(05) 82647-2 \quad$ [Crossref]

08. Kaplan SL. Clinical manifestations, diagnosis, and prognostic factors of bacterial meningitis. Infect Dis Clin North Am. 1999;13(3):579-594, vi-vii.

doi: 10.1016/s0891-5520(05)70095-7 [Crossref]

09. Haruda FD. Meningitis- viral vs bacterial. Pediatr. 2003;112(2)447-448.

doi: $10.1542 /$ peds.112.2.447 [Crossref]

10. Simon L, Gauvin F, Amre DK, Saint-Louis $P$, Lacroix J. Serum procalcitonin and C-reactive protein levels as markers of bacterial infectiona systematic review and meta-analysis. Clin Infect Dis. 2004; Jul-15;39(2)206-17.

doi: 10.1086/421997 [Crossref]

11. Suberviola B, Castellanos-Ortega A, GonzálezCastro A, García-Astudillo LA, Fernández-Miret B. Prognostic value of procalcitonin, C-reactive protein and leukocytes in septic shock. Med Intensiva. 2012;36(3)177-184.

doi: $10.1016 /$ j.medin.2011.09.008 [Crossref]

12. Alavi SM, Shokri S. Can serum procalcitonin measurement help monitor the treatment of acute bacterial meningitis?- A prospective study. Caspian J Intern Med. 2012;3(1)382-385.

[Crossref]

13. Ibrahim KA, Abdel-Wahab AA, Ibrahim AS. Diagnostic value of serum procalcitonin levels in children with meningitis- a comparison with blood leukocyte count and C-reactive protein. J Pak Med Assoc. 2011;61(4)346-351.

[Crossref]

14. Viallon A, Guyomarc'h P, Guyomarc'h S, Tardy B, Robert $F$, Marjollet $O$, et al. Decrease in serum procalcitonin levels over time during treatment of acute bacterial meningitis. Crit Care. 2005;9(4)R344-R350.

doi: $10.1186 /$ cc3722 [Crossref]
15. Oberhoffer M, Stonans I, Russwurm S, Stonane $E$, Vogelsang $H$, Junker $U$, et al. Procalcitonin expression in human peripheral blood mononuclear cells and its modulation by lipopolysaccharides and sepsis-related cytokines in vitro. J Lab Clin Med. 1999;134(1)49-55.

doi: 10.1016/s0022-2143(99)90053-7 [Crossref]

16. Prat C, Domínguez J, Rodrigo $C$, Giménez $M$, Azuara M, Blanco $S$, et al. Use of quantitative and semiquantitative procalcitonin measurements to identify children with sepsis and meningitis. Eur J Clin Microbiol Infect Dis. 2004;23(2)136-138.

doi: $10.1007 / \mathrm{s} 10096-003-1066-4 \quad$ [Crossref]

17. Mills GD, Lala HM, Oehley MR, Craig AB, Barratt $K$, Hood D, et al. Elevated procalcitonin as a diagnostic marker in meningococcal disease. Eur J Clin Microbiol Infect Dis. 2006;25(8)501-509.

doi: $\quad 10.1007 / s 10096-006-0179-y \quad$ [Crossref]

18. Gendrel D, Raymond J, Assicot M, Moulin F, Iniguez $J$, Lebon $P$, et al. Measurement of procalcitonin levels in children with bacterial or viral meningitis. Clin Infect Dis. 1997;24(6)1240-1242.

doi: $10.1086 / 513633$ [Crossref]

19. Schwarz S, Bertram M, Schwab S, Andrassy K, Hacke W. Serum procalcitonin levels in bacterial and abacterial meningitis. Crit Care Med. $2000 ; 28(6) 1828-1832$.

doi: 10.1097/00003246-200006000-00024 [Crossref]

20. Monneret G, Labaune JM, Isaac C, Bienvenu F, Putet G, Bienvenu J. Procalcitonin and Creactive protein levels in neonatal infections. Acta Paediatr. 1997;86(2)209-212. doi: $10.1111 /$ j.1651-2227.1997.tb08870.x [Crossref] 